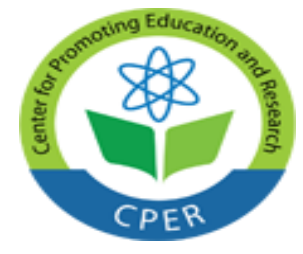

VOL: 1, ISSUE: 2

February/2019

https://ijssppnet.com/

E-ISSN: $x x x x-x x x x$

(C) Center for Promoting Education and Research (CPER) USA

WwW.cpernet.org

\title{
INFLUENCE OF EMOTIONAL INTELLIGENCE AND CULTURAL ORGANIZATION ON ORGANIZATIONAL PERFORMANCE THROUGH CITIZENSHIP BEHAVIOR OF ORGANIZATIONPT. DHARMA ELECTRINDO MANUFACTURING
}

\author{
Nur Hariyanto ${ }^{1}$, Abdul Rivai ${ }^{2}$, Suharto $^{3}$ \\ Faculty of Economics \\ Universitas Krisnadwipayana Jakarta \\ Campus UNKRIS Jatiwaringin \\ P.O. Box 7774 / Jat CM. Jakarta 13077 \\ Indonesia
}

Abstract

Thus study aims to determine the influence of emotional intelligence and organizational culture on organizational performance, influence of emotional intelligence on the performance of an organization partially, the influence of organizational culture on organizational performance partially, the influence of emotional intelligence on organizational performance through citizenship behavior of organizations, the influence of organizational culture on performance organization through through organizational citizenship behavior. The study was conducted at PT. Dharma Electrindo Manufacturing. Sampling using random samples involving 300 employees. Analysis of data using path analysis.

Based on data analysis found that the variable of emotional intelligence and organizational culture influence on organizational performance simultaneously. Emotional intelligence variables affect the performance of an organization partially. Organizational culture variables affect the performance of an organization partially. Organizational citizenship behavior variables on the performance of organization affect the performance of an organization partially.

\section{Keywords: emotional intelligence, organizational culture, organizational citizenship behavior, organizational performance}

\section{JEL Classification: L21, L25}

\section{Introduction}

Companies need employees who have reliable behavior. One such behavior is organizational citizenship behavior. Thus behavior arises because the feeling as a member of the organization and is satisfied if it can do something more to the organization. Feeling as the members are satisfied when doing a much only happen if employees have a positive perception of the organization.

Such behavior will not be rewarded either directly or sanctions do or not, but the constructive attitude shown by the OCB employee will give positive ratings (Nielsen, 2012). Organizations need employees who joined the behaviors of good citizenship, as in statements constructive about working groups and their organizations, helping others in their team, volunteer for additional activities, avoiding unnecessary conflicts, show attention to property organizations, respect the spirit as well as the rules and rule-based, and are willing to tolerate disruption and losses that are associated with precarious employment (Robbins, 2008: 30).

Thus organizational behavior can affect the performance of the organization. The performance of the organization is generated by organizations that include results (outcomes) that the financial performance such as 


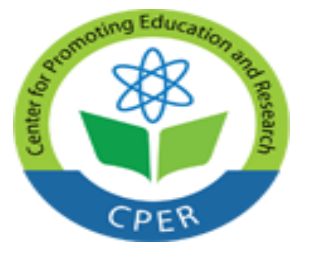

VOL: 1, ISSUE: 2

February/2019

https://ijssppnet.com/

E-ISSN: $x x x x-x x x x$

(C) Center for Promoting Education and Research (CPER) USA

WwW.cpernet.org

profit, as measured by return on assets, return on investment and so on, the performance of markets such as the expansion of market shares, and sales. Besides the return of shareholders a return of shareholders and increase the economy of shareholders.

In some areas of the organization's performance can also be measured by other things such as strategic planning, operations, and finance, legal and organizational development. In developing the institution or organization is a necessity to survive in the competitive world climate.

Another influential factor is the organizational performance on emotional intelligence. Emotional intelligence as the ability to monitor and control their feelings of themselves and others, and use those feelings to fuse thought and action. Desire chooses intelligence rooted in biology and is values in one or more cultural atmosphere.

Knowledge of normal development and the development of talented individuals; information regarding the destruction of cognitive skills with a damaged brain condition; research on the incredible population, including people who are extraordinary, people are very smart in a certain field but barely understand other fields, children with autism; data on the evolution of the learning process in several millennia; consideration of cross-cultural learning process; psychometric research, including examination of the correlation in rates; psychological training and research, particularly measures to realize transfer traffic tasks.

Organizational culture also affects the performance of the organization. That organizational culture is a system of shared meaning in an organization that determines the higher level how employees act. Organizational culture is a value system that is believed by all members of the organization and learned and applied and developed on an ongoing basis which serves as the overall system. Organizational culture as the dominant values is disseminated within the organization that made the philosophy of employee who became a guide for the organization's policy in managing employees and customers.

Organizational culture as a series of values and norms that control the organization's members to interact with each other and with suppliers, customers, and others outside the organization. Organizational culture consists of the final state that the organization seeks to achieve (terminal value) and model drives organizational behavior (instrumental values). Ideally, the instrumental value to help organizations achieve terminal objectives. Actually, different organizations have different cultures because they process setting terminal and instrumental values are different.

\section{Literature Review}

\section{Emotional Intelligence}

Steiner (1997) explains understanding emotional intelligence is an ability to understand the emotions themselves and others, as well as knowing how emotions themselves expressed to increase the maximum ethical as personal power.

In line with Thus definition, Mayer and Solovey (Goleman, 1999; Davies, Stankov, and Roberts, 1998) revealed emotional intelligence as the ability to monitor and control their feelings of themselves and others, and use those feelings to fuse thought and action.

Desire choose intelligence rooted in biology, and are values in one or more cultural atmosphere, how does one actually recognize the "intelligence"?

Knowledge of normal development and the development of talented individuals; information regarding the destruction of cognitive skills with a damaged brain condition; research on the incredible population, including 


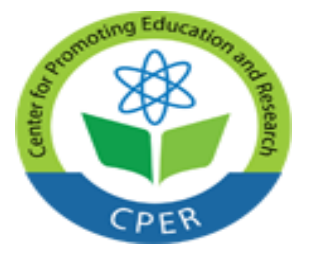

VOL: 1, ISSUE: 2

February/2019

https://ijssppnet.com/

E-ISSN: $x x x x-x x x x$

\section{(C) Center for Promoting Education and Research (CPER) USA}

WwW.cpernet.org

people who are extraordinary, people are very smart in a certain field but barely understand other fields (idiotsavant), children with autism; data on the evolution of the learning process in several millennia; consideration of cross-cultural learning process; psychometric research, including examination of the correlation in rates; psychological training and research, particularly measures to realize transfer traffic tasks.

Only candidates who satisfy the intelligence of all or most of the criteria chosen as intelligence can be trusted. A more complete discussion of each of these criteria for"intelligence" and the seven bits of intelligence proposed however can be read in Frames of Mind (1983) Howard Gardner's essays.

Emotional intelligence was first brought up in 1990 by psychologist Peter Salovey from Harvard University and John Mayer of the University of New Hampshire to explain the emotional qualities that seem essential to success. Salovey and Mayer define emotional intelligence or EQ is often referred to as a subset of social intelligence that involves the ability to monitor social feeling that involves the ability for others, sort through them all and use thus information to guide our thoughts and actions (Yulisubandi, 2009).

Emotional intelligence is strongly influenced by the environment, do not be sedentary, can change at any time. For the role of the environment, especially parents in childhood influence in the formation of emotional intelligence. Gardner (in Goleman, 2009) says that it is not just one kind of intelligence that is monolithic which is important for success in life, but there is a spectrum of intelligence were wide with seven main varieties namely linguistic, math/logic, spatial, kinesthetic, musical, interpersonal and intrapersonal, Thus intelligence named by Gardner as a personal intelligence by Goleman referred to as emotional intelligence.

Based on the intelligence that is expressed by the Gardner, Salovey (in Goleman, 2009) chose interpersonal and intrapersonal intelligence to serve as the basis for uncovering the emotional intelligence of the individual self. According to a person's emotional intelligence is the ability to recognize emotions, managing emotions, motivating oneself, recognizing emotions in others (empathy) and the ability to build relationships (in cooperation) with other people.

According to Cooper and Sawaf (1999), emotional intelligence is the ability to sense, understand and effectively apply the power and sensitivity of emotions as a source of energy, information, corrections, and human influence. Emotional intelligence requires surveillance feeling to learn to recognize, appreciate the feelings in themselves and others and respond appropriately, effectively implement energy of emotions in everyday life. Where emotional intelligence is also the ability to use emotions effectively to achieve the goal to build a productive and achieve success.

Goleman (2009) defines that emotional intelligence is a person's ability which involves a series of various capabilities to be able to motivate yourself, endure frustration, controlling impulsive needs or impulses, do not overestimate the pleasure and distress, able to regulate reactive needs, keeping stress-free, does not cripple the ability of thinking and the ability to empathize with others, as well as the principle of trying and praying. Goleman also adds emotional intelligence is the other side of cognitive intelligence that plays a role in human activities which include self-awareness and impulse control, persistence, zeal and self-motivation and empathy and social skills. Emotional intelligence is a more directed effort to identify.

Based on these descriptions, it can be concluded that emotional intelligence is the ability to sue themselves to learn to acknowledge and respect the feelings of self and others and to respond appropriately, implement effectively energy of emotions in life and work every day, as well as a person's ability to recognize emotions self-esteem, managing emotions, motivating oneself, recognizing emotions in others (empathy) and the ability to build relationships (in cooperation) with other people. 


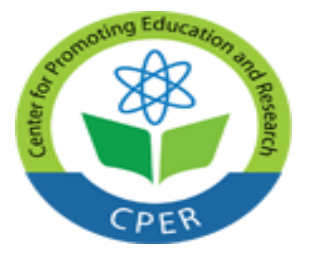

VOL: 1, ISSUE: 2

February/2019

https://ijssppnet.com/

E-ISSN: $x x x x-x x x x$

(C) Center for Promoting Education and Research (CPER) USA

WwW.cpernet.org

\section{Culture Organizational}

Robbins (2008) states that organizational culture is a system of shared meaning in an organization that determines the higher level how employees act. Organizational culture is a value system that is believed by all members of the organization and learned and applied and developed on an ongoing basis which serves as the overall system. Robbins (2008) states: organizational culture Refers to a system of shared meaning held by members that distinguish the organization from other organization. Thus system of shared meaning is, on closer analysis, a set of key characteristics that the organization values.

Further Robbins (2008) argues that: "The culture of the organization as the dominant values are disseminated within the organization that made the philosophy of employee who became a guide for the organization's policy in managing employees and customer.

Organizational culture as a series of values and norms that control the organization's members to interact with each other and with suppliers, customers, and others outside the organization. Organizational culture consists of the final state that the organization seeks to achieve (terminal value) and model drives organizational behavior (instrumental values). Ideally, the instrumental value to help organizations achieve terminal objectives. Actually, different organizations have different cultures because they process setting terminal and instrumental values are different.

Organizational culture has a broad meaning. According to Dessler (2006), organizational culture is characteristic values, traditions, and behavior of employees in the company. According to Luthans (2006) are the organizational culture norms and values that guide the behavior of members of the organization. Each member will behave in accordance with the prevailing culture in order to be accepted by the environment.

Schein in Luthan (2006) defines organizational culture as a pattern of basic assumptions that are found, created or developed by a certain group with the intention that the organization learns to overcome or cope with his problems arising from external adaptation and internal integration that is already running pretty good, so it needs to be taught to new members as the correct way to perceive, think and feel pleased with these problems.

\section{Organizational Citizenship Behavior}

Organizational Citizenship Behavior (OCB) is a behavior that is not part of the task that has been formally required for an employee but overall encouraging the effective functioning of the organization (Robbins, 2008). In terms of the effectiveness of the organization, individuals in a team need to have behaviors that support. Such behavior is not only appropriate behavior only role (in the role) but is expected to bring extra role behavior of the individual so that the fabric can be more solid teamwork and can work optimally for the organization (Bennet in Krishnan 2008). In addition to the above definition, Organ (in Podsakoff, 2000) also provides those five dimensions of organizational citizenship behavior (OCB):

1. Altruism: behaviors that have an influence in helping colleagues in charge.

2. Conscientiousness: behavior that becomes part of the employees who carry out tasks that exceed the minimum requirements.

3. Sportsmanship: the feelings of the employees to refrain from complaints about things that are not preferable.

4. Courtesy: the behavior of the individual parts to replace others in the organization about changes affecting their work.

5. Civic virtue: behavior that becomes part of individuals who indicated that they participate in the company. 


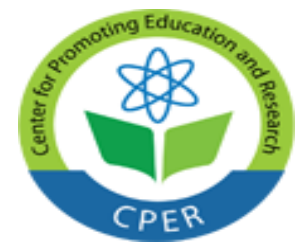

VOL: 1, ISSUE: 2

February/2019

https://ijssppnet.com/

E-ISSN: $x x x x-x x x x$

\section{(C) Center for Promoting Education and Research (CPER) USA}

WWW.cpernet.org

Organizational behavior is a science which studies human behavior in an organization and how that behavior has an impact on the behavior of the member's organization. In the end, OCB become a variable in organizational behavior. Organ gives a definition that OCB is free behavior of individuals that are explicitly or indirectly recognized by the formal system, and in the aggregate function effectively and efficiently in an OCB organization. , as proposed by organ, are as follows organizational citizenship behavior: individual behavior that is discretionary, not directly or explicitly recognized by the formal reward system, and in the aggregate promotes the efficient and effective functioning of the organization.

More Organ effect that the aggregate function is referring to the people in a group, department, or organization. If only one person, OCB does not have a significant impact on an organization, but according to the Organ, if an organization, in the aggregate, its members have a good $\mathrm{OCB}$, its impact on the organization will be felt significantly.

In general terms, OCB is behavior that makes people do things that are not described in the job and there is no reward or recognition for his actions consciously and on his own, such as helping a co-worker to do his job or help the boss even got outside work hours set. Thus behavior is behavior that can enhance organizational effectiveness.

Indicators that can be set are as follows:
a. The nature of Helping
b. Attitude Sport if
c. Fidelity or Loyalty
b. Compliance with the Organization.

\section{Organizational Performance}

According to Richard et al (2009) in James (2012) the performance of the organization is generated by organizations that include results (outcomes) that the financial performance such as profit, as measured by return on assets, return on investment and so on, the performance of the market (product market performance ) such as the expansion of market share, and sales. Besides the return of shareholders a return of shareholders and increase the economy of shareholders.

In some areas of the organization's performance can also be measured by other things such as strategic planning, operations, finance, legal and organizational development. In developing the institution or organization is a necessity to survive in the competitive world climate. The purpose of productivity associated with the development of that organization (Shrestha, 2005). Small organizations that have a desire to continue to grow and become large. The growing organization in order development itself.

Measuring the performance of the organization according to the concept of PBM SIG (the performance-based management special interest group is to perform monitoring and reporting programs and pay attention to objectives achieved. Performance is measured based on the activities of the program to run, products, and services resulting from.

Besides according to Kaplan and Norton (1992) the organization's performance should be measured only in terms of concept no finance but also of non-financial. Performance can be measured by productivity, quality, consistency and so on. On the other hand measure organizational performance outcomes, behavioral and normative level, education and concepts generated including management development (Richard, 2002). 
VOL: 1, ISSUE: 2

February/2019

https://ijssppnet.com/

E-ISSN: $x x x x-x x x x$

(C) Center for Promoting Education and Research (CPER) USA

WwW.cpernet.org

\section{Research Methods}

\section{Research Design}

Thus research uses explanatory analysis approach. Thus means that each of the variables presented in the hypothesis will be observed by testing the causal relationship of independent variables on the dependent variable.

That phenomenon can be designed through the following mathematical functions:

\section{Model 1 (one)}

Simultaneously influence between X1 (emotional intelligence) and X2 (cultural organizations) to variable $\mathrm{Y}$ (organizational performance) can be formulated with:

$Y=\mathrm{F}(\mathrm{X} 1, \mathrm{X} 2)$

Assuming probability predictor variables are the same $(P \# 0,000) /<0,05$

\section{Model 2 (two)}

The influence of the independent variables X1 (emotional intelligence) to Y (organizational performance) can be formulated with:

$Y=f\left(X_{1}\right)$

Assuming probability is not the same predictor variables $(P \# 0,000) /<0,05$,

\section{Model 3 (three)}

Partial effect between X2 (cultural organizations) to Y (organizational performance) can be formulated with:

$Y=f\left(X_{2}\right)$

Assuming probability is not the same predictor variables.

4. Model 4 (four)

Partial effect between X3 (organizational citizenship behavior) to $\mathrm{Y}$ (organizational performance) can be formulated with:

$Y=\mathrm{F}(\mathrm{X} 3)$

Assuming probability is not the same predictor variables $(P \# 0,000) /<0,05$

\section{Model 5 (five)}

Partial effect of X1 (emotional intelligence) to Y (organizational performance) through X3 (citizenship behavior) can be formulated with the organization:

$\mathrm{X} 3=\mathrm{f}(\mathrm{X} 1)$

$Y=\mathrm{F}(\mathrm{X} 3)$

Assuming probability is not the same predictor variables $(P \# 0,000) /<0,05$

\section{Model 6 (six)}

Partial effect of $\mathrm{X} 2$ (cultural organizations) to $\mathrm{Y}$ (organizational performance) through variable $\mathrm{X} 3$ (organizational citizenship behavior) can be formulated with:

$\mathrm{X} 3=\mathrm{f}(\mathrm{X} 2)$

$Y=\mathrm{F}$ (X3)

Assuming probability is not the same predictor variables $(P \# 0,000) /<0,05$, 
VOL: 1, ISSUE: 2

February/2019

https://ijssppnet.com/

E-ISSN: $x x x x-x x x x$

(C) Center for Promoting Education and Research (CPER) USA

WWW.cpernet.org

\section{Object of Research}

The study was conducted inPT. Dharma Electrindo Manufacturing in Cikarang, Bekasi. The company provides a wide range of automobile parts.

\section{Population and Sample}

The population is a generalization region consisting of the objects/subjects that have a certain quantity and characteristics defined by the researchers to learn and then drawn conclusions (Sugiyono, 2007). Samples were towing the majority of the population to represent the entire population, (Surakhmad, 2010). The sample used by the author in Thus study was firm.

The total number of employees 1200 people in the field of organization. Employees Slovin taken using the formula for $n=1200 /(1+0.05 * 1200)=300$. Samples are taken randomly.

\section{Results and Discussion}

\section{Effect of Emotional Intelligence and Organizational on Culture Organizational Performance}

Linear analysis model can be based on calculations using SPSS program as follows. Table 1. Results of the analysis of the first equation

\section{Coefficients}

\begin{tabular}{|c|c|c|c|c|c|}
\hline \multirow[b]{2}{*}{ Model } & \multicolumn{2}{|c|}{$\begin{array}{l}\text { Unstandardized } \\
\text { coefficients }\end{array}$} & \multirow{2}{*}{\begin{tabular}{|c|} 
Standardized coefficients \\
beta \\
\end{tabular}} & \multirow[b]{2}{*}{$t$} & \multirow[b]{2}{*}{ Sig. } \\
\hline & B & Std. Error & & & \\
\hline 1 (Constant) & 15.454 & 1,247 & & 12.396 &, 000 \\
\hline $\begin{array}{l}\text { Emotional } \\
\text { Intelligence }\end{array}$ & , 756 &, 056 & , 484 & 13.501 &, 000 \\
\hline $\begin{array}{l}\text { Organizationa } \\
\text { l Culture }\end{array}$ &, 566 &, 036 & , 562 & 15.683 &, 000 \\
\hline
\end{tabular}

a. Dependent Variable: Organizational Performance

Based on the tables above, the simultaneous structural equations can be described as follows: $\mathrm{Y}=0,484 \mathrm{X} 1+0,562 \mathrm{X} 2$ F count can be obtained from the following table:

Table 2. Calculate the F value equations simultaneously

ANOVAa

\begin{tabular}{|ll|r|r|r|c|c|}
\hline \multicolumn{1}{|c|}{ Model } & Sum of Squares & df & mean Square & F & Sig. \\
\hline 1 & Regression & 6625.232 & 2 & 3312.616 & 248.712 &, $000 \mathrm{~b}$ \\
& residual & 3955.764 & 297 & 13.319 & & \\
Total & 10580.997 & 299 & & & \\
\hline
\end{tabular}

a. Dependent Variable: Organizational Performance

b. Predictors: (Constant), Organizational Culture, Emotional Intelligence

Based on the above table it is known that the value of f-count equal to 248.712 and significance of 0.00 . Thus value is less than 0.05. Thus means variable emotional intelligence and organizational culture influence on organizational performance simultaneously. The magnitude of the effect of the independent variable on the dependent variable can be seen from the following values of $r$ squared.

Table 3. Values $r$ squared regression model first 


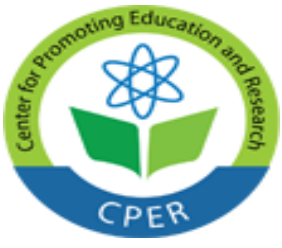

VOL: 1, ISSUE: 2

February/2019

https://ijssppnet.com/

E-ISSN: $x x x x-x x x x$

(C) Center for Promoting Education and Research (CPER) USA

WWW.cpernet.org

Model Summaryb

\begin{tabular}{|l|l|r|r|r|r|}
\hline Model & $\mathrm{R}$ & R Square & $\begin{array}{c}\text { Adjusted R } \\
\text { Square }\end{array}$ & $\begin{array}{c}\text { Std. Error of the } \\
\text { Estimate }\end{array}$ & Durbin-Watson \\
\hline 1 &, $791 \mathrm{a}$ &, 626 &, 624 & 3.64953 & 1.362 \\
\hline
\end{tabular}

a. Predictors: (Constant), Organizational Culture, Emotional Intelligence

b. Dependent Variable: Organizational Performance

Based on the above table it is known that the value of $\mathrm{r}$ squared of $62.6 \%$ means that the variables of emotional intelligence and organizational culture influence on organizational performance by $62.6 \%$ while the rest influenced by other variables that are not incorporated into the model equations.

\section{Influence of Emotional Intelligence on Organizational Performance}

The results of the analysis of the influence of emotional intelligence on the organization's performance can be partially seen in the following table.

Table 4. Results of the analysis of the second regression equation

Coefficients

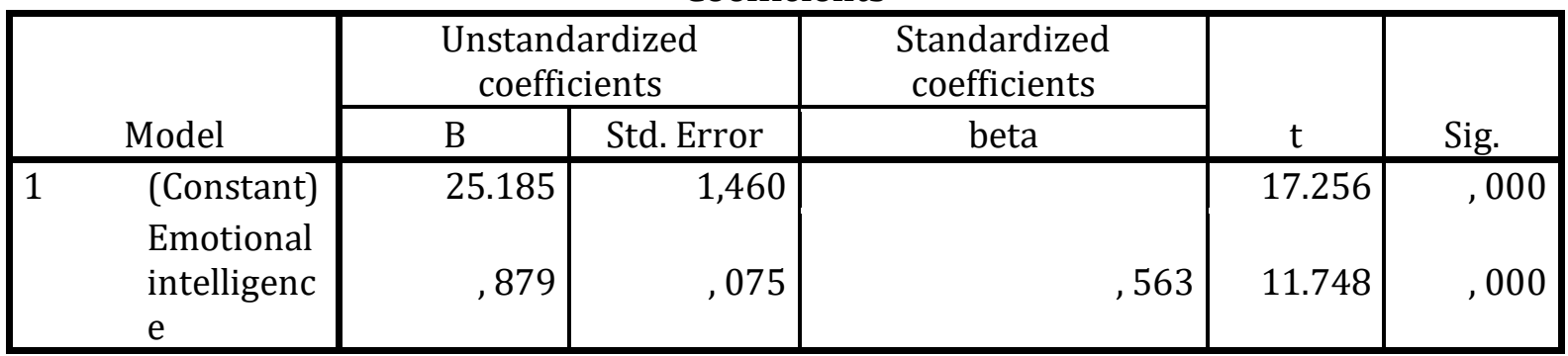

a. Dependent Variable: Organizational Performance

The structural equation of the above data can be seen as follows: $\mathrm{Y}=0,563 \mathrm{X} 1$

Based on the chart above analysis it is known that emotional intelligence coefficient of 0.563 . $T$ value of 11.748 . The significant value of 0.00 . The significance value smaller than 0.05 . Thus means that the emotional intelligence variables affect the performance of an organization partially. The magnitude of the effect of emotional intelligence on the organization's performance can be seen in the following table.

Table 5. Values $r$ squared second equation

\begin{tabular}{|l|r|r|r|r|}
\hline \multicolumn{1}{|c|}{ Model Summary } \\
\hline 1 & $\mathrm{R}$ & R Square & Adjusted R Square & $\begin{array}{c}\text { Std. Error of the } \\
\text { Estimate }\end{array}$ \\
\hline
\end{tabular}

a. Predictors: (Constant), Emotional Intelligence

Based on the above table it can be seen $r$ squared value of 0.317 . Thus means that the influence of emotional intelligence variables on the performance of $31.7 \%$ and the rest influenced by other variables not included in the model equations.

\section{Influence of Organizational Culture on Organizational Performance}

Results of the analysis of the influence of organizational culture on performance can be partially seen in the following table. 


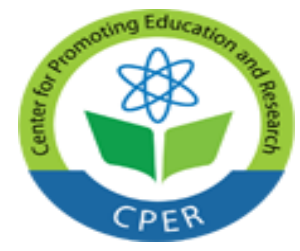

VOL: 1, ISSUE: 2

February/2019

https://ijssppnet.com/

E-ISSN: $x x x x-x x x x$

(C) Center for Promoting Education and Research (CPER) USA

Table 6. Results of the analysis of the third regression equation

\section{Coefficientsa}

\begin{tabular}{|c|c|c|c|c|c|}
\hline \multirow[b]{2}{*}{ Model } & \multicolumn{2}{|c|}{ Unstandardized coefficients } & \multirow{2}{*}{\begin{tabular}{|c} 
Standardized coefficients \\
beta
\end{tabular}} & \multirow[b]{2}{*}{ 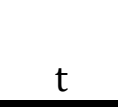 } & \multirow[b]{2}{*}{ Sig. } \\
\hline & $\mathrm{B}$ & Std. Error & & & \\
\hline 1 (Constant) & 28.455 & 1,004 & & 28.339 &, 000 \\
\hline $\begin{array}{l}\text { Organizational } \\
\text { Culture }\end{array}$ &, 634 & , 045 & 63 & 13.998 &, 000 \\
\hline
\end{tabular}

a. Dependent Variable: Organizational Performance

The structural equation of the above data can be seen as follows: $Y=0,630 \mathrm{X} 2$

Based on the chart above analysis it is known that the coefficient of 0.630 organizational culture. T value of 13.998 . The significant value of 0.00 . The significance value smaller than 0.05 . Thus means that the organizational culture variables affect the performance of an organization partially. The magnitude of the influence of organizational culture on organizational performance can be seen in the following table.

Table 7. The third equation $r$ squared

Model Summary

\begin{tabular}{|l|r|r|r|c|}
\hline Model & $\mathrm{R}$ & R Square & Adjusted R Square & $\begin{array}{c}\text { Std. Error of the } \\
\text { Estimate }\end{array}$ \\
\hline 1 &, $630 \mathrm{a}$ &, 397 &, 395 & 4.62829 \\
\hline
\end{tabular}

a. Predictors: (Constant), Organizational Culture

Based on the above table it can be seen $r$ squared value of 0.397 . Thus means that the influence of organizational culture variables on organizational performance by $39.7 \%$ and the rest influenced by other variables not included in the model equations.

\section{Influence of Organizational Citizenship Behavior on Organizational Performance}

The analysis results of work organizational citizenship behavior on the performance can be seen in the following table.

Table 8. Results of the fourth regression equation analysis

Coefficients

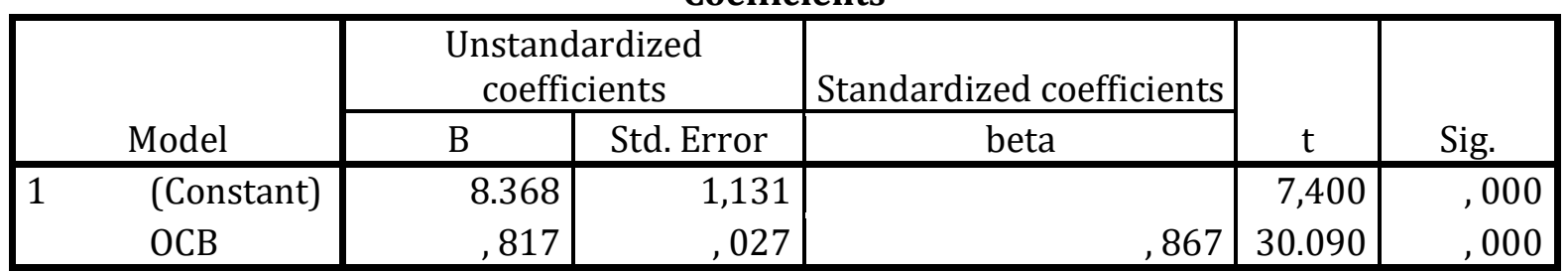

a. Dependent Variable: Organizational Performance

The structural equation of the above data can be seen as follows: $\mathrm{Y}=0,867 \mathrm{X} 3$

Based on the chart above analysis it is known that organizational citizenship behavior coefficient of 0.67 . $T$ value of 30.090. The significant value of 0.00 . The significance value smaller than 0.05 . Thus means that the variable organizational citizenship behaviors affect the organization's performance partially. The magnitude of the effect of organizational citizenship behavior on organizational performance can be seen in the following table. 
VOL: 1, ISSUE: 2

February/2019

https://ijssppnet.com/

E-ISSN: $x x x x-x x x x$

(C) Center for Promoting Education and Research (CPER) USA WWW.cpernet.org

Table 9. Values $r$ squared fourth equation

Model Summary

\begin{tabular}{|c|r|r|r|r|}
\hline Model & $\mathrm{R}$ & R Square & Adjusted R Square & $\begin{array}{c}\text { Std. Error of the } \\
\text { Estimate }\end{array}$ \\
\hline 1 &, $867 \mathrm{a}$ &, 752 &, 752 & 2.96521 \\
\hline
\end{tabular}

a. Predictors: (Constant), OCB

Based on the above table it can be seen $r$ squared value of 0.752 . Thus means that the effect of variable organizational citizenship behavior on organizational performance and the remaining $75.2 \%$ is influenced by other variables that are not incorporated into the model equations.

4. Effect of Emotional Intelligence on Organizational Performance Through Organization Citizenship Behavior Influence coefficients emotional intelligence work organizational citizenship behavior against visible on the table below

Table 10. The effect of emotional intelligence on organizational citizenship behavior work

\section{Coefficients}

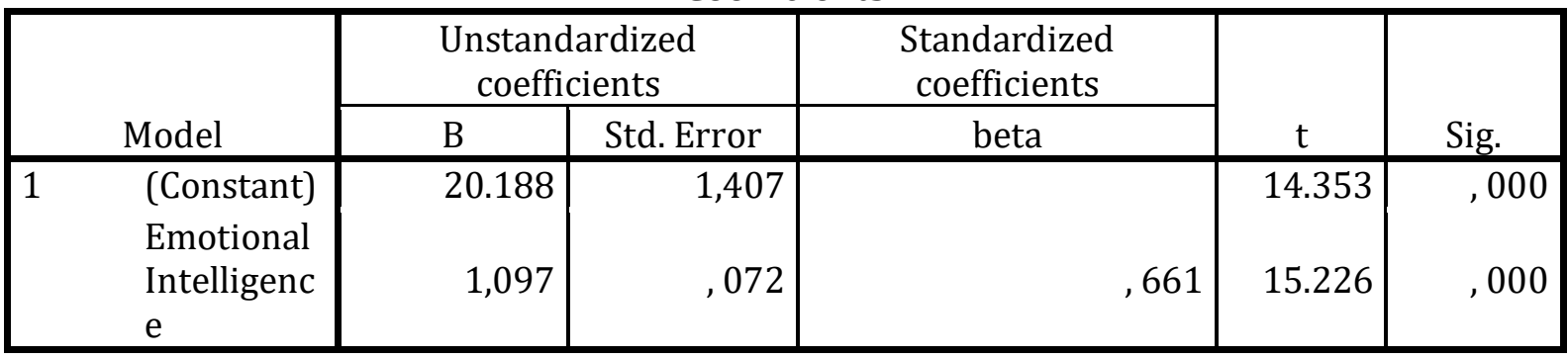

a. Dependent Variable: OCB

Based on the above table it is known that the influence of emotional intelligence on organizational performance is .563 . The influence of emotional intelligence on the performance through organizational culture is $0.661 \times 0.867=0.573$. In Thus case, the indirect effect is greater than the direct effect so that it can be said that the organizational citizenship behavior variables work as an intervening variable.

\section{Influence of Organizational Culture on Organizational Performance Through Organization Citizenship Behavior}

The coefficient of organizational culture on organizational citizenship behavior work can be seen in the following table.

Table 11. The coefficient of the influence of organizational culture on organizational citizenship behavior work

Coefficients

\begin{tabular}{|c|c|c|c|c|c|}
\hline \multirow[b]{2}{*}{ Model } & \multicolumn{2}{|c|}{$\begin{array}{c}\text { Unstandardized } \\
\text { coefficients }\end{array}$} & \multirow{2}{*}{$\frac{\text { Standardized coefficients }}{\text { beta }}$} & \multirow[b]{2}{*}{$\mathrm{t}$} & \multirow[b]{2}{*}{ Sig. } \\
\hline & B & Std. Error & & & \\
\hline 1 (Constant) & 23.471 &, 867 & & 27.073 & 000 \\
\hline $\begin{array}{l}\text { Organizational } \\
\text { Culture }\end{array}$ & , 830 &, 039 &, 776 & 21.206 & 000 \\
\hline
\end{tabular}

a. Dependent Variable: OCB 


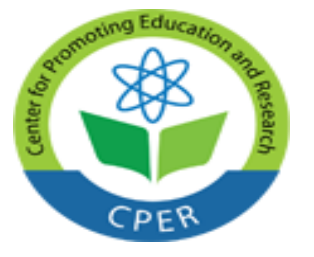

VOL: 1, ISSUE: 2

February/2019

https://ijssppnet.com/

E-ISSN: $x x x x-x x x x$

\section{(C) Center for Promoting Education and Research (CPER) USA}

WWW.cpernet.org

Based on the previous table it can be seen that the direct effect of organizational culture on organizational performance is .630. While the influence of organizational culture on organizational performance through organizational citizenship behavior is $0.776 \times 0.867=0.673$. In Thus case smaller than the direct influence of indirect influence so that it can be said that the organizational citizenship behavior variables work as an intervening variable.

\section{Conclusion}

\section{Conclusions and Recommendations}

Variable emotional intelligence and organizational culture influence organizational performance simultaneously. F value calculated at 248.712 and significance of 0.00 . Thus value is less than 0.05 . R squared value of $62.6 \%$ means that the variables of emotional intelligence and organizational culture influence on organizational performance by $62.6 \%$ while the rest influenced by other variables that are not incorporated into the model equations.

Emotional intelligence variables affect the performance of an organization partially. $\mathrm{T}$ value of 11.748 . The significant value of 0.00 . The significance value smaller than 0.05 . R squared value of 0.317 . Thus means that the influence of emotional intelligence variables on the performance of $31.7 \%$ and the rest influenced by other variables not included in the model equations.

Organizational culture variables affect the performance of an organization partially. $\mathrm{T}$ value of 13.998. The significant value of 0.00 . The significance value smaller than 0.05 . $R$ squared value of 0.397 . Thus means that the influence of organizational culture variables on organizational performance by $39.7 \%$ and the rest influenced by other variables not included in the model equations.

Organizational citizenship behavior variables affect the performance of an organization partially. T value of 30.090. The significant value of 0.00 . The significance value smaller than 0.05 . $\mathrm{R}$ squared value of 0.752 . Thus means that the effect of variable organizational citizenship behavior on organizational performance and the remaining $75.2 \%$ is influenced by other variables that are not incorporated into the model equations.

The influence of emotional intelligence on organizational performance is .563. The influence of emotional intelligence on the performance through organizational culture is $0,661 \times 0,867=0.573$. In Thus case, the indirect effect is greater than the direct effect so that it can be said that the organizational citizenship behavior variables work as an intervening variable.

The direct effect of organizational culture on organizational performance is .630. While the influence of organizational culture on organizational performance through organizational citizenship behavior is $0,776 \times 0,867=$ 0.673. In Thus case smaller than the direct influence of indirect influence so that it can be said that the organizational citizenship behavior variables work as an intervening variable.

\section{Recommendations}

Emotional intelligence is an ability to understand the emotions themselves and others, as well as knowing how emotions themselves expressed to increase the maximum ethical as personal power. Emotional intelligence can be improved by taking into account the introduction of emotions, managing emotions, motivating oneself, recognizing emotions in others and build relationships.

Organizational culture as a pattern of basic assumptions that are found, created or developed by a certain group with the intention that the organization learns to overcome or cope with his problems arising from external adaptation and internal integration that has been going pretty well, so it needs to be taught to new members as the correct way to perceive, think and feel pleased with these problems. Organizational culture can be improved by taking into account, the member identity, group emphasis, people focus, unit integration, control, risk tolerance, reward criteria, conflict tolerance, and end orientation means.

Organizational citizenship behavior (OCB) is a behavior that is not part of the task that has been formally required for an employee but overall encouraging the effective functioning of the organization. The behavior can be improved by taking into account the attitude of altruism (happy to help) co-workers, conscientiousness attitude (being part of the 


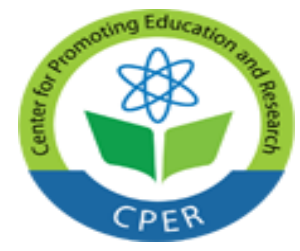

VOL: 1, ISSUE: 2

February/2019

https://ijssppnet.com/

E-ISSN: $x x x x-x x x x$

(C) Center for Promoting Education and Research (CPER) USA

WWW.cpernet.org

work), Sportsmanship attitude (attitude did not complain), the attitude of courtesy (could replace the role) and civic (can participate).

\section{References}

Ac Nielsen. (2011). The Digital media and Habits Attitudes of South East Asian Performance. Harvard Business Review, January-February: $\quad 1 . \quad$ Consumers, diaksespadatanggal 9 November 2017, dari http://www.scribd.com/doc/71370794/The-digital-media-and-habitsattitudes-of-South-East-AsianConsumers\#download.

Albert ,Richard., Spiro, Stephen., Jett, James (2008). Clinical.respiratory. Medicine .Phil Adelphia: Elsevier.

Arcot, J. danShrestha, A. (2005).Folate :Method Of Analysis. Trend in Food Science and Technology.253-266.

Arthur, Jr., W., Bennett Jr., W., Edens, P.S., \& Bell, S.T. (2003). Effectiveness of Training in Organizations: A Meta-Analysis of Design and Evaluation Features. Journal of Applied Psychology.Vol. 88 No. 2.234-245.

Cooper, K., Sawaf, Ayman. (1998). Executive EQ :Kecerdasanemosional. AlihBahasa: AymanSawat. Jakarta :Gramedia.

Gardner, Howard. Hatch, Thomas. (1989). Multiple Intelligences Go to School Educational Implications of the Theory of Multiple Intelligence. Educational Researcher.Vol. 18.No. 8. pp. 4-10.

Gardner, H. (2003). KecerdasanMajemuk :TeoridalamPraktek. Alihbahasa : Arvin Saputra. Batam: Interaksara.

Goleman, D. (1997). KecerdasanEmosi (Terjemahan T. Hermaya). Jakarta: PT GramediaPustakaUtama. Goleman, D. (1998). Working With Emotional Intelligence. New York: Bantam Books

Goleman, D. (2002). Working With Emotional Intelligence.KecerdasanEmosiuntukMencapaiPuncakPrestasi. (Terjemahan Alex Tri KantjonoWidodo). Jakarta : PT. GramediaPustakaUtama.

Kaplan, R. S., \& Norton, D. P. (1992). The Balanced Scorecard - Measures that Drive

Luthans, Fred. (2006). PerilakuOrganisasi, (AlihBahasa V.A Yuwono, dkk), EdisiBahasa Indonesia, Yogyakarta: ANDI.

Meyer, J.P. and Allen N.J. (2007). Commitment in the Worldplace Theory Reserch and Application, California: Sage Publications.

Podsakoff, P. M., et al. (1997). Organizational Citizenship Behavior and the Quantity and Quality of Work Group Performance. Journal of Applied Psychology, Vol. 82, No. 2, 262-270.

Robbins, Stephen P. dan Timothy A. Judge. (2008). PerilakuOrganisasiEdisi ke-12, Jakarta: SalembaEmpat.

Steiner, G.S., (1997), Strategic Marketing Planning, New York: Free Press.

Sugiyono, (2007), MetodologiPenelitianBisnis, PT. Gramedia, Jakarta

Winarno, Surakhmad, (2010), "PengantarPenelitianIlmiahdasarMetodeTeknik”, Tarsito, Bandung. 


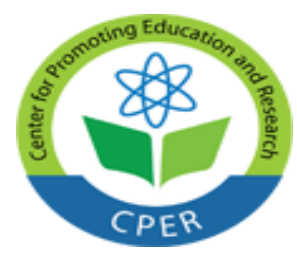

VOL: 1, ISSUE: 2

February/2019

https://ijssppnet.com/

E-ISSN: $x x x x-x x x x$

(C) Center for Promoting Education and Research (CPER) USA WwW.cpernet.org

(http://mindscapecenter.com/artikel/kecerdasan\%20emosi.pdf 